\title{
Human Rights for Women's Development in Multidimensional: A Step towards Gender Equality in Education
}

\author{
Andrey Shastri \\ University of Lucknow, Uttar Pradesh. India \\ shastriandrey59@gmail.com
}

\section{ARTICLE HISTORY \\ Received : 2019-03-09 \\ Revised : 2019-06-29 \\ Accepted : 2019-07-09}

\section{KEYWORDS}

Women

Gender equality

Human right

Education

\begin{abstract}
Women's educational human rights and gender equality is one of the burning topics nowadays. Following the gender equality framework proposed by United Nations in its Millennium Summit in 2000 declared "Gender equality and women empowerment". This present study tries to review gender equality for women in many aspects, including the major concern in this review, i.e., education and human right. After analyzing several documents in the net during the collection period, this study sees that women have achieved a lot. However, yes still they are lagging in terms of equality in education and human right. The fact showed women are far lagging and leave alone on the question of gender equality. The present paper explores and highlighted these issues as the central questions related to women's rights and also attempts to wrestle with the few challenges that faced by the women education system in India as a specific example. At last, this paper also try to highlight some strategy as to upgrade the status of women in society, ever since this study believes that Educating a woman will uplifts her life as well as the quality of the nation.
\end{abstract}

irrespective of gender, to develop their capabilities and freedoms. Some aspects of this equality are the freedom to attend school, to learn and participate there in safety and security, to develop identities that tolerate others, and to enjoy a range of economic, political, and cultural opportunities and valued outcomes. Education is one of the points of interest in context to women empowerment and development since it encourages them to react to the difficulties, to stand up to their standard appearance, and upset their living. With the goal that we can't disregard the significance of education and development about women empowerment, India is ready to be a superpower, a created nation by 2020 .

For most of the people in India the concept of Vasud Haibe Kutumbakan and Nara Narayan in classical Indian story contained the spirit of human rights in the Indian Constitution human rights education is the only guarantee of human dignity. It also led towards the promotion of world peace and prospects for all. Human rights education guarantees fundamental human rights and freedom to all. Further, Basic principles of human rights have gained universal acceptance against all deprivations. In this democratic country like India, it is an inalienable right to live in freedom, to enjoy equality, to be treated justly equally, and to live in peace. However, through universally accepted, human rights still to be realized in the daily lives because human beings are found in chains everywhere. For some reason, they are denied their basic human rights. For the equality and empowerment of deprived section, minorities, women, it is, therefore, essential that society recognizes their 
basic human rights towards everyone and learns to respect and enforce them. hence, the key towards equality and women's empowerment is all about recognize and the enforcement of women's human rights.

However, the Universal Declaration of Human Rights 1948 has unequivocally included all these rights as basic rights of human beings. and everyone is entitled to enjoy equally all basic rights of human beings, without any kind of discrimination in race, color, sex, language, religion, or any other kind of status. A reiteration of women's human rights was made at the 1993 World Conference on Human Rights. The full and equal participation of women in political, civil, economic, and cultural life at the national, regional and international level and eradication of all forms of discrimination on the grounds of sex are the priority objectives of the international community".

\section{Method}

This is a descriptive research paper based on primary and secondary data from the net and local manuscripts. It is descriptive and analytical. In this paper, an endeavor has been taken to examine the woman human rights in the different field especially in education area and also their status overall in India. Data have been found out from different website, books, research papers and e-journals collectively.

\section{Women's Educational Empowerment}

Since colonial days women emerged out to be an interest group. During the pre-independence era, they were mostly excluded from the concept of equality. There was a distinction between male and female. But later, they had waged a struggle for the recognition of their rights as human being. Although women execute distinctive in the society from breadwinner till daughter-in-law. It is a well-known fact that women's contribution to the country's development is equal to that of their male counterparts, still they are facing several difficulties. A popular saying goes 'While educating a man benefits him alone, educating a woman benefits the whole family and society. It is a proven fact that children of educated women enjoy high education standards and fare better than illiterate mothers. Educated women manage their homes better as they support their families economically, financially, and emotionally.

Women's education in India assumes an essential part in the general development of the nation. It does not just make a difference in the advancement of half of the human capital, however in enhancing the standard of living.

Women as a core group of concern in any themes related to development. United Nations in its Millennium Summit in 2000 declared 'Gender Equality and Women Empowerment' as one among the eight 'Millennium Development Goal' to be achieved by the year 2015. Even theSDG4 focuses on education around the world. Ensure inclusive and equitable quality education and promote lifelong learning for all. Education is a human right and a force for sustainable development and peace. ... Ambitions for education are essentially captured and given more importance in Sustainable Development Goal 4 (SDG 4) of the 2030 Agenda, which aims to "ensure inclusive and equitable quality education and promote lifelong learning opportunities for all" by 2030. Further, the term Women's empowerment implies the ability of the women take all the important decisions independently related to her throughout her life span definitely that ensure her success in all fields.

However, these goals are meant for the development of all human beings. In fact, often, women not only in India but across globally are deprived of their basic rights. Among the social rights, the Declaration mentions in Article 25 that everyone has a right to a standard of living adequate for the health and well-being of himself or herself. Article 26 proclaims that everyone has the right to education. Education shall be free, at least in the elementary stage. Later on, the International Covenants on Civil Rights and Political Rights and on Economic, Social and Cultural Rights of 1996 also meant in this Declaration.

\section{Discrimination against Women}

The relationship between gender and violence is complex and even goes hand in hand. Several evidences suggest, that existing various gender inequalities increase the risk of violence by men against women. There are many forms of violence against women; this briefing focuses on intimate partners' violence, the most common form. Although further research is needed, evidence shows that school, community, and media interventions can promote gender equality and prevent violence against women by challenging stereotypes that give men power over women. There is a denial of human rights. However, gender equality can be defined as: Equal treatment of women and men in laws and policies and equal access to resources and services within families, communities, and society at large.

The historical nature of women's rights and the status of women in modern society show the way in which the context of the rights of women is a determined phenomenon of discrimination against women. Therefore, the discussion about the conceptualization of the notion of women's rights should be focused on the very notion of discrimination against women and the ways in which it manifests.

Gender equality is not only a fundamental human right but a necessary foundation for a peaceful and sustainable world. The exclusion of women at different workplaces, at home makes their less involved in every spheres. Equal access to education, 
decent work, and representation in political and economic decision-making processes are not only rights women should have, but they are even going to benefit humanity a large scale. By investing in women's empowerment, we not only make progress on Goal 5 of the Sustainable Development Goals, we also procure on sustainable growth.

Historically and traditionally, women have been eliminated on the basis of discrimination, and they face many types of violence in everyday life. Regarding this, the emphasis has to be on elimination of discrimination. that is why women's human rights have been set out in a document entitled " The convention on the Elimination of All forms of Discrimination of against women " violates the principles of equality of rights and respect for human dignity, is an obstacle to the participation of women on equal terms with mean in every sector like political, social, and economical life. Article 5 of the convention has prescribed that State parties must take measures to modify the social and cultural patterns of conduct of men and women. Article 10 focuses on equal right to education. Empowerment of women thus only enhances after the elimination of all kinds of discrimination in every arena of society. Though India has ratified CEDAW, it needs to take many more appropriate initiatives before it can fulfill its obligations under CEDAW.

\section{Different Factsheets on Violence on Women}

Literally, the meaning of discrimination can be explained as an unfavorable treatment to anyone based on sex, race and so on. It is considered as an obstacle to the achievement of the objectives of equality, development, and peace. India is a religious and male-dominated society where women are considered as secondary to men. Very less examples are seen where women are considered as equal to men. Still preference of son birth is more common and celebrates with great joy almost in every community. Gender-based discrimination in different forms starts right after the birth, and it continues throughout the life cycle. Again, the numbers of people are very few who treat girls equal to sons. Girls are treated as liabilities that parents had to fulfill as soon as possible. The next part basically sets out a span of areas related to the human rights abuse of women in India.

5.1 Missing of girl child: For the first time " missing women" term was used by Prof. Amartya Sen. usually for the sake of money small girl child and even married sold to another man. An average of 200 Children goes missing in India every day. Girls made up 52,049 missing cases in 2019, while boys accounted for 21,074 cases. As compared to 2018, the total number of cases of missing children increased by almost $9 \%$.
5.2 Dowry Death cases: Disputes related to dowry death are one of the major concerns related to women's human rights. India reports the highest total number of dowry deaths, with 8,391 such deaths reported in 2010, meaning there are 1.4 deaths per 100,000 women. Female dowry deaths resulted around 40 to 50 percent of all female homicides recorded annually in India and representing a stable trend over the period 1999 to 2016. The killing of women just for the sake of few money resulted in the horrible crime and up to the death of women. even though Section 498A of the Indian Penal Code strongly deals with the person responsible for marital cruelty and has declared that giving and taking money in the form of dowry is a crime but then also still frequently practiced in India.

5.3 Child Marriage: India has the largest number of brides in the world - one-third of the global total. Although in India there is strict laws related to it, but still, it is more prevalent in different parts of India. Child marriage is driven by gender inequality and the belief that girls are somehow inferior to boys. Patriarchal social norms considered to be major reason behind this crime. Child marriage is more common among poorer household with many families as they married off their daughters to reduce their perceived economic burden. Girls are often married off at a very young age because in return, less dowry is expected for younger brides.

5.4 Education: Education is one of the most critical areas related to women empowerment. It is the need of hour. The education of women, in particular, is seen as providing the key to securing the intergenerational transfer of knowledge from one generation to another and will help in reducing gender gaps. Thus, gender equality in every arena and especially in the education sector, upholds the central place in the global policy discourse on human and social development. Achievements are particularly visible in education sector, but still, there are huge gaps. Education is a critical component of the fundamental and universal rights of everyone. Efforts have been made at global level, and global consensus have been generated on how to address gender inequalities in education.

Undoubtedly, Women's education guarantees better advancement of human progress. Education is the point of interest in context to women empowerment since it encourages them to react towards the difficulties and also stand up to their standard appearance. Women education in India has additionally been a noteworthy distraction of both the administration and common society as taught women can assume an essential part in the improvement of the nation. Education is the point of reference of women's empowerment since it empowers them to reacts to the difficulties, to go up against their conventional part, and change their life. 
In India, according to 2011 Census, over all literacy rate is $74.04 \%$ whereas the male and female literacy rate is $82.14 \%$ and $65.46 \%$ respectively. The literacy rate in Northern States of India is very low as compared to others. Rajasthan over all literacy rate is $66.11 \%$ male literacy rate is $79.11 \%$ and female literacy rate is $52.12 \%$ respectively. On the whole, a huge gap of gender inequality exists in most of the state. From the different statistical reports and Census 2011, reveals that the male female literacy gap is approximately $16 \%$. The major problem in terms of women is illiteracy and discrimination which they face since from childhood. It is a major issue of concern for whole India and even across the world. A huge disparity can be seen in economical, educational and social level.

According to the Article 21 of the Indian Constitution which made provision for compulsory for the government to provide free education to everybody. In spite of this effort still it is a distant dream to achieve full literacy rate in terms of women. efforts of Sarva Skisha Abhiyan has been successful in bringing the girl child again back to schools, yet their retention rate in the school is very less as compared to boys. Several studies and researches have shown the data that there is a gradual drop out of girls as soon they move up towards the higher section. This data is excess in rural areas. It happens because parents still treat girls as liabilities and boys as economic assets which will look after them till the old ages. Not only in rural areas but in modern society still it is believed that girls should help mothers in domestic works. The parents take more interest in boys' education as compared to girl's education. Parents did not want to spend so much money in terms of girls' education. Thus, the universalization of primary education in India remains a remote daydream as related to girl's education.

5.5 Rape: Again, it is one of the very critical issue related to women and girls. According to the latest NCRB report, 2019 saw over 4 lakh reported cases of crimes committed against women, up from 3.78 lakh in 2018 and 3.59 lakh cases in 2017. NCRB reported 32,033 rape cases which translate to a shocking 88 rape cases a day -- and this is just $10 \%$ of all crimes against women. All these data show the horrible effect of crime related to girls and women. According to NCRB 2019 statistics, Rajasthan reported the highest number of rapes among Indian states. The Criminal Law (Amendment) Act 2013 made to deal with the rape cases in India, it came into force after the brutal gang-rape case in Delhi.

\section{A Step towards Gender Equality in Education on Global Level}

First of all, women must be treated as a person in the society rather than just a puppet of the male hands. They should be given a primary position rather than the secondary one. Although there are many women in every field of life sometimes even as a bread earner, but still, they are not on equal footing as men. Yet they experience helplessness in eliminating gender inequalities from society. The National Commission for women has been set up for the welfare of women. A multi-layered strategy needs to be developed to assess the core causes of violence against women. The idea of self- reliant, independent women taking independent decisions of their life can be achieved only by educating women which is going to help them in achieving economic independence as well as knowledge and awareness about their rights.

Different women's organizations must try to empower women by changing the attitudes of the society towards the harmful traditional practices which is prevailing in society. Various women organizations and several NGOs are aimed to rebuild the lives and confidence among women and also to lower the several cruel practices. Violence against women can be controlled only when societal norms and attitudes change their perspective regarding women and should treat them as a human being with full respect.

\section{Conclusion}

Thus, in brief, the Millennium Development Goal on gender equality and women empowerment can only be realized truly in India in all over the world when several cruel practices like female infanticide, child marriage, dowry death, sexual abuse and many more is eliminated from society, and people should change their mind set regarding women. Then only gender quality and women's right will make true meaning in reality. As today women empowerment and women's rights are major concerns of the $21 \mathrm{t}$ century. Women's education in India plays a key role in the social and economic development of the country. Educating a woman uplifts her life as well as the quality of her life and her entire family. It is a fact that any educated woman will definitely support the education of her children, especially a girl child and provide better guidance to her children. An educated woman will easily imbibe an independent and progressive outlook in her children. More importantly, an educated woman in a society like India will assist in reducing the infant mortality rate and control the blossoming of the population. Empowerment. The education of women in India plays a significant and very important role in improving living standards in the country. Definitely, a much higher women's literacy rate improves the quality of life both home and outside of home, and it also help in encouraging and promoting education of children, especially female children, and in reducing the infant mortality rate.

Society is more biased towards the male child in respect of education, nutrition, and other opportunities. The root cause of this type of attitude lies in the belief that male child inherits the clan in India and girl are 
still considered to be a burden on the family. The main purpose of this research paper is to acquire understanding of the human rights of women. The main reason that the rights of women have been undermined is due to the extent of patriarchal society and male dominance in the family. In this so-called male dominant society, preference was given to male children. There were practices of female feticide and female infanticide. Females were considered as liabilities, which would lead to expenditure, whereas males were regarded to be the assets, which would generate wealth for their families in the future and will take care of their parents in old age. The decisionmaking and other powers and authorities were vested in the hands of males. The responsibilities of the females were limited to performing the household chores, child development and looking after the family members. Proper Education enables a person to differentiate between appropriate and inappropriate, learn to make wise decisions, work towards the welfare of the community and for the nation. Government activities alone would not be adequate to accomplish this objective. Society must step up with regards to make an atmosphere in which there is no sexual orientation segregation, and women should have full chances of self-basic leadership and taking an interest in social, political, and monetary existence of the nation with a feeling of equity then only in true sense we can have an educated society. At last, Hillary Clinton stated that -- " Human rights are women's rights, and women's rights are human rights".

\section{References}

Bhandari, S. (2014). An Analysis of Women Education in India. Educationia Confab, 3(2), 15.

Bhat,R.A. (2015). Role of Education in the Empowernment of Women in India, Journal of Education and Practice, 6(10), 188-191.

Census of India (2011). Government of India. Retrieved from http://www.census2011.co.in/

Das, B., Khawas. V (2009) Gender Issues in Development Concerns for the $21^{\text {st }}$ century, Rawat Publication, New Delhi.

Dey, P. (2015). Gender Gap in Education-An Indian Human Capital Formation Concern. Global Journal of Human-Social Science Research, 5(1).1-11

Ghose, M. (2011). Gender bias in education in India. Journal of Economic and Social Development, 7(2), 118-28.

John, M.E. (2008) Women's studies in India: A Reader, Penguin, New Delhi.

Kapur, P. (2001) Empowering The Indian Woman, Publication Division, New Delhi.
Kingdom, G.G. (2002) The Gender Gap in Edicational attainment in India: How much can be expalined, Journal of Development Studies,39(2), 25-23.

Khatri,Rita. (2016) The Role of Education Towards Women Empowernmen in India, International Journal of Advanced Reserach, 4(11), 550-555.

Khan, N.A. (2021) Educational Strategies for Youth Empowernment in Conflict Zones: Transforming Trauma, Palgrave Macmillain, New York.

Mishra , R.C. (2010) Women In India Towards Gender Equality, Author Press, Delhi.

Muralidharan. K., Seth. K. (2013) Bridging Educating Gender gaps in Developing Countries: The Role of Female Teachers, NBER working Paper No. 19341.

Pant, S.K. (2016) Gender Bias in girl Child Education, Kanishka Publishers, New Delhi.

Reily, N. (2009) Women's Human Rights; Seeking Gender Justice in a Globalizing Age, Wiley Publishers.

Ross, D. S. (2008) Women's Human rights, The International and Comparative Law Casebook, University of Pennsylvania press.

Saryal, S. (2014) Women's Rights in India: Problems and Prospects, International Research Journal of Social Sciences, 3(7), 49-53

The world Survey, Role of Women in development (2014), Gender equality and Sustainable development, United Nation.

Watkins, K. (2000), Oxfam Education Report, Oxfam GB, U.K. 